\title{
Movement of transgenic plant-expressed Bt Cry1AC proteins through high trophic levels
}

\author{
W. Wei ${ }^{1,2}$, T. H. Schuler ${ }^{2}$, S. J. Clark $^{3}$, C. N. Stewart Jr ${ }^{4}$ \& G. M. Poppy ${ }^{2,5}$ \\ 1 Key Laboratory of Vegetation and Environmental Change, Institute of Botany, Chinese Academy of Sciences, Xiangshan, Beijing, China \\ 2 Plant and Invertebrate Ecology Division, Rothamsted Research, Harpenden, Hertfordshire, UK \\ 3 Biomathematics and Bioinformatics Division, Rothamsted Research, Harpenden, Hertfordshire, UK \\ 4 Department of Plant Sciences and Landscape Systems, University of Tennessee, Knoxville, TN, USA \\ 5 Division of Biodiversity and Ecology, School of Biological Sciences, University of Southampton, Southampton, UK
}

\section{Keywords}

ELISA, exposure, natural enemies, non-target insects, oilseed rape, tritrophic interactions

\section{Correspondence}

Wei Wei, Institute of Botany, Chinese Academy of Sciences, 20 Nanxincun, Xiangshan, Beijing 100093, China.

E-mail: weiwei@ibcas.ac.cn

Received: March 15, 2007; accepted: September 26, 2007.

doi: $10.1111 / j .1439-0418.2007 .01242 . x$

\begin{abstract}
The movement of Bacillus thuringiensis (Berliner) (Bt) Cryl Ac endotoxin through high trophic levels was assessed to help elucidate the effects of Bt toxin on non-target insects. The diamondback moth (Plutella xylostella L., Lepidoptera: Plutellidae), the parasitic wasp (Cotesia vestalis Haliday, Hymenoptera: Braconidae) and the predatory green lacewing Chrysoperla carnea (Stephen) (Neuroptera: Chrysopidae) were used as a model system in this laboratory study. Bt-resistant $P$. xylostella larvae fed CrylAcexpressing transgenic oilseed rape (OSR, Brassica napus L., Cruciferae), before and after parasitization by $C$. vestalis, consumed CrylAc with the ingested plant material but only a proportion of Cryl Ac consumed was recovered from the bodies and faeces of $P$. xylostella larvae. CrylAc was not detected in newly emerged parasitoid larvae. In contrast, CrylAc was detected in C. carnea larvae fed on resistant P. xylostella larvae reared on Bt OSR. However, no CrylAc could be detected in C. carnea larvae when the lacewings were transferred to $P$. xylostella larvae reared on conventional OSR and tested $24-48 \mathrm{~h}$. The metabolizing ability of CrylAc is discussed for the larvae of P. xylostella and C. carnea.
\end{abstract}

\section{Introduction}

Over the last 10 years, numerous studies have investigated the effects of insect-resistant transgenic plants on non-target beneficial insects. Transgenic plants expressing genes from Bacillus thuringiensis (Berliner) (Bt) have received most attention (Orr and Landis 1997; Pilcher et al. 1997; Hilbeck et al. 1998a,b, 1999; Schuler et al. 1999, 2001). Most of these studies investigated the effects of Bt endotoxin on the survival and development of non-target insects. The movement of Bt toxin through trophic levels has received less attention. While several studies have quantified the amount of Bt protein in phytophagous insects (Head et al. 2001; Raps et al. 2001; Dutton et al. 2002; Harwood et al. 2005), in predatory arthropods fed artificial diets (e.g. lacewing, Romeis et al. 2004), and in the field (Harwood et al. 2005; Zwahlen and Andow 2005), there has been less attention to measurements of total amounts of $\mathrm{Bt}$ protein through trophic levels and none to its possible metabolism in arthropod natural enemies that had preyed on insects exposed to Bt plants. Head et al. (2001) detected higher bioactivity of the Bt toxin CrylAb in tissues of larvae of Ostrinia nubilalis (Hübner) (Lepidoptera: Pyralidae), Helicoverpa zea (Boddie) and Agrotis ipsilon (Hufnagel) (Lepidoptera: Noctuidae) fed on diet containing higher levels of synthetic Bt protein than in those feeding on diet with lower Bt levels. However, no insecticidal activity was detected within the tissues of these insects that fed on transgenic CrylAb-expressing maize 
(MON810) (Head et al. 2001), which was probably because of the low transgene expression (Nguyen and Jehle 2007). In contrast, Shi et al. (2006) reported the presence of insecticidal activity of $\mathrm{Bt}$ protein residual inside larval bodies and faeces of Spodoptera exigua Hübner (Lepidoptera: Noctuidae) when feeding on transgenic Bt cotton (Gossypium hirsutum L., Malvaceae).

The ability to assess direct exposure levels in target and non-target insects is of great interest in both risk assessment and for a fundamental understanding of tritrophic interactions. Detection and quantification of $\mathrm{Bt}$ proteins in higher trophic levels can also help to study direct and indirect (or host/prey-mediated) effects of transgene products combining with information on its insecticidal activity (Shi et al. 2006) and the susceptibility of the organisms at higher trophic levels (Romeis et al. 2006). There has been considerable controversy about the prey-mediated effects on the predatory Chrysoperla carnea (Stephen) (Neuroptera: Chrysopidae) (Hilbeck et al. 1998a,b, 1999; Dutton et al. 2002; Romeis et al. 2004, 2006; Hilbeck and Schmidt 2006). The prey/host-mediated effects could be excluded upon the application of resistant herbivores.

Oilseed rape (OSR, Brassicae napus L., Cruciferae) is an important worldwide crop and is often damaged by lepidoptera. Diamondback moth (Plutella xylostella L., Lepidoptera: Plutellidae) is one of the most important pests of cruciferous plants throughout the world. The parasitic wasp (Cotesia vestalis (plutellae), Hymenoptera: Braconidae) is a solitary endoparasitoid and an important enemy of P. xylostella (Talekar and Shelton 1993). Chrysoperla carnea feeds on a wide range of soft-bodied small insects, including aphids, lepidopteran larvae and insect eggs and therefore it is an important enemy in many agricultural systems throughout the world (McEwen et al. 2001). All three larval instars of $C$. carnea can prey on P. xylostella larvae. Chrysoperla carnea is the most often used predator species in laboratory tests to study the impact of transgenic plants on arthropod natural enemies (Dutton et al. 2003; Lovei and Arpaia 2005).

Although Bt transgenic OSR has not yet been approved for commercial planting, it has been widely field-tested and has proven to be a very useful experimental system to assess the ecological risks of $\mathrm{Bt}$ crops. The transgenic line we used in this study has been used in several tier trophic studies with $P$. xylostella as the second trophic level and $C$. vestalis and $C$. carnea as the third level, in which no direct effect of Bt plants on natural ene- mies was found (e.g. Schuler et al. 1999, 2001, $2004,2005)$. In addition, gene flow and hybridization frequently happens between the OSR and its wild and cultivated relatives (Wei et al. 1999; Stewart et al. 2003), which would enhance the exposure of insects to Bt toxin in the field (Le et al. 2007). Thus it is of great interest to detect and quantify the movement of Bt toxin through the trophic levels described above.

In this study, our model system comprised of the following components: first trophic level - transgenic OSR expressing the Bt toxin CrylAc active against various lepidopterans (Stewart et al. 1996); second trophic level - the target pest, P. xylostella, a Brassica specialist; and third trophic level - two non-target insects that are feed on $P$. xylostella larvae: the parasitic $C$. vestalis and the predatory $C$. carnea. The result would provide important evidence in understanding the mechanisms behind reported effect on non-target insects of transgenic Bt crops.

\section{Materials and Methods}

\section{Plant materials}

The spring OSR line (Brassica napus L. (Cruciferae) cV. Oscar, line O52) used in this study expressed a synthetic Bt crylAc gene under the control of the CaMV 35S promoter (Stewart et al. 1996). All plants used in this study were the progeny of a single selfed $\mathrm{F}_{3}$ plant. Untransformed conventional [wild type (WT)] plants of the parent cultivar Oscar was used as control plants. Another WT OSR strain (cv. Falcon) was used to maintain the $P$. xylostella culture. All OSR plants were grown in $13 \mathrm{~cm}$ pots in a glasshouse set at $20^{\circ} \mathrm{C}$ and a minimum day length of 14 h. Red cabbage (Brassica oleracea L., Cruciferae) was purchased from a supermarket. Plant leaf discs of diameter $3.8 \mathrm{~cm}$ were used in this study of previous top leaves at the 5-week stage (Wei et al. 2005), unless stated otherwise. Leaf discs from similarly positioned leaves on these same plants of known Bt protein concentration were used.

\section{Insect materials}

To enable the exposure of the natural enemies to plenty of Bt toxin accumulated in the larval bodies of $P$. xylostella, a Bt-resistant strain of $P$. xylostella (NO-QA), originally selected with microbial Bt (Tabashnik et al. 1997), was used in this study. The parasitic wasp C. vestalis (plutellae) was reared on P. xylostella at Rothamsted Research (as described by 
Schuler et al. 2004). Chrysoperla carnea larvae were purchased from Koppert Biological Systems, Koppert UK Ltd., Haverhill, Suffolk, UK.

\section{Measurement of time needed for P. xylostella larvae to replace their gut content}

Second instar P. xylostella larva was placed individually in empty wells of a 12-well ELISA plate and fed red cabbage for $24 \mathrm{~h}$. The diet was then changed to OSR and the larvae observed until the colour of their faeces changed from red to green. Faeces were collected after $\mathrm{l}$ and after $2 \mathrm{~h}$, moistened with water, placed on a white filter paper and their colour determined. A further 12 larvae were fed OSR followed by red cabbage and observed until their faeces changed from green to red. This approach established how many hours of feeding were necessary to replace the gut contents, an important factor in developing assays to investigate movement of $\mathrm{Bt}$ toxin through trophic levels.

\section{Bt protein levels in P. xylostella larvae and their faeces}

Second instar P. xylostella larvae of the NO-QA strain were transferred to WT OSR leaf discs after feeding on Bt OSR leaf discs to investigate the distribution of CrylAc inside larval guts and faeces after a given duration of feeding on non-transgenic leaf discs, with the aims to check for any possible metabolism of the protein by the larvae and to justify the application of Bt leaf disc in the following tier trophic assays. The minimum feeding time allowed on WT discs was $4 \mathrm{~h}$ to enable enough time for complete gut content replacement. In experiment 1,10 P. xylostella larvae of the same strain (NO-QA) were placed on each of three Bt discs with known CrylAc concentration (table 1, Wei et al. 2005) and each disc was kept individually in a Petri dish for $72 \mathrm{~h}$. The 10 larvae in each Petri dish were then all transferred together to a WT OSR leaf disc. No active feeding was observed and the feeding on WT disc was near zero. Larvae and faeces were collected from one of these three dishes with WT leaf discs at 4, 16 and $33 \mathrm{~h}$ after transfer, respectively, and stored at $80^{\circ} \mathrm{C}$. In Experiment 2, the CrylAc concentration of leaf discs from five plants at five-leaf stage (Wei et al. 2005) was quantified using ELISA and the mean concentration (table 1) used in combination with total feeding areas on all Bt OSR leaf discs in individual Petri dishes to calculate the approximate amount of total ingested CrylAc toxin. One of four Bt OSR leaf discs and 10 larvae were placed in each of four Petri dishes for $72 \mathrm{~h}$ before transfer to WT leaf discs. Active insect feeding was observed in this experiment. Larvae and faeces were collected from one of the four discs at each of $4,12,20$ and $48 \mathrm{~h}$ after transfer, respectively, and stored at $-80^{\circ} \mathrm{C}$, to quantify CrylAc toxin levels presented in larvae bodies. Total feeding area $\left(\mathrm{mm}^{2}\right)$ on each Bt OSR leaf disc was calculated using the MATLAB method described below. Total CrylAc ingested by the 10 larvae feeding on each disc was estimated by multiplying the feeding area with the CrylAc concentration in the disc. The experiments were conducted at $25 \pm 2{ }^{\circ} \mathrm{C}$ with a light : dark cycle of $18: 6 \mathrm{~h}$. The humidity was maintained by adding drops of water occasionally.

Table 1 Presence of Cry1Ac proteinin in larvae of $P$. xylostella and their faeces after switching foods from transgenic Bt oilseed rape to wild type (WT) oilseed rape

\begin{tabular}{|c|c|c|c|c|c|c|c|}
\hline & \multirow{2}{*}{$\begin{array}{l}\text { Duration on } \\
\text { WT plant discs (h) }\end{array}$} & \multirow{2}{*}{$\begin{array}{l}\text { Cry1Ac content } \\
\text { in Bt plant discs }\left(\mathrm{ng} / \mathrm{mm}^{2}\right)\end{array}$} & \multicolumn{2}{|c|}{$\begin{array}{l}\text { Feeding area }\left(\mathrm{mm}^{2}\right) \\
\text { on plant discs }\end{array}$} & \multirow{2}{*}{$\begin{array}{l}\text { Total Bt ingested } \\
\text { (ng) }\end{array}$} & \multirow{2}{*}{$\begin{array}{l}\text { Bt residuals } \\
\text { in larvae (ng) }\end{array}$} & \multirow{2}{*}{$\begin{array}{l}\text { Bt in } \\
\text { faeces (ng) }\end{array}$} \\
\hline & & & Bt plant & WT plant & & & \\
\hline \multirow[t]{3}{*}{ Experiment 1} & 4 & 0.055 & 306 & $\mathrm{Null}^{2}$ & 16.76 & 2.04 & 9.0874 \\
\hline & 16 & 0.048 & 441 & $\mathrm{Null}^{2}$ & 21.25 & 1.89 & 8.6505 \\
\hline & 33 & 0.063 & 645 & $\mathrm{Null}^{2}$ & 40.74 & 0.65 & 8.8988 \\
\hline \multirow[t]{4}{*}{ Experiment 2} & 4 & $0.092 \pm 0.0110^{1}$ & 781 & 76 & 71.59 & 1.44 & 9.77 \\
\hline & 12 & & 268 & 397 & 24.57 & 0.062 & 12.62 \\
\hline & 20 & & 227 & 402 & 20.81 & 0.054 & 13.82 \\
\hline & 48 & & 557 & 619 & 51.06 & 0.046 & 24.31 \\
\hline
\end{tabular}

Bt plant: transgenic oilseed rape plants, WT: wild type plants of oilseed rape.

${ }^{1}$ The data based on five leaves.

${ }^{2}$ The feeding area was too small to be calculated and was assumed as null. 


\section{Detection of CrylAc protein in parasitoids and hosts}

Leaf discs from the leaves of 5-week old Bt OSR plants, the Cryl Ac concentrations of which had been quantified using ELISA $(653 \pm 94 \mathrm{ng} / \mathrm{g}$ fresh leaf weight or $0.092 \pm 0.011 \mathrm{ng} / \mathrm{mm}^{2}$ leaf area, $\mathrm{n}=5$, Wei et al. 2005), were fed to Bt-resistant third instar NO-QA P. xylostella larvae for $24 \mathrm{~h}$ to ensure host larvae contained some CrylAc toxin and used in following assays. Bt leaf discs were replaced once during the feeding process because of leaf disc depletion by feeding. The P. xylostella larvae were then exposed to $C$. vestalis females for $24 \mathrm{~h}$ for parasitization. Ten hosts were placed with one parasitoid and one $\mathrm{Bt}$ OSR leaf disc in a Petri dish and held at $25 \pm 2{ }^{\circ} \mathrm{C}$ with a light: dark cycle of $18: 6 \mathrm{~h}$. The leaf disc was not replaced after parasitization. After the larvae stopped feeding, the parasitized $P$. xylostella larvae were transferred to a clean container, and the parasitoid larvae collected immediately as they emerged from their hosts. Care was taken not to contaminate the parasitoid larvae with host frass pellets present in the Petri dish. The host larvae were collected in the same time of parasitoid collecting while the faeces were collected whenever the Bt OSR leaf disc was replaced and when new parasitoids were collected. Parasitoid larvae, their respective hosts as well as the faeces of those hosts were transferred separately into plastic tubes, frozen in liquid nitrogen and stored at $-80^{\circ} \mathrm{C}$. Bt Cryl Ac toxin in parasitoids and hosts from the same dish were measured in the same ELISA test. Plutella xylostella larvae from which no parasitoids emerged were also collected and stored individually at $-80^{\circ} \mathrm{C}$ for further ELISA tests. The total leaf feeding area was calculated with the aid of MATLAB software (see below) in order to estimate the total amount of Cryl Ac the host larvae had ingested. Total CrylAc present in the host larvae was estimated by summing the CrylAc concentration of all hosts collected from each dish to measure the proportion of Bt CrylAc inside larval bodies to the totally consumed amount. The whole procedure was repeated on two separate occasions using six and five replicate dishes, respectively. Plutella xylostella larvae fed WT Oscar and parasitized by C. vestalis were used as controls on both occasions. On the first occasion, most hosts in four of the six Petri dishes died and the surviving larvae (13 in all) were combined together in one dish. Before the combination, all leaf discs from these four dishes were collected to calculate the total feeding area of larvae, and all faeces and dead bodies were collected to detect total Bt toxin. These data were used to partially estimate total Bt toxin ingested by larvae and present in the bodies and faeces. Data from the combined dish were used to complete the calculation.

\section{Detection of CrylAc in predatory lacewings}

First instar $P$. xylostella larvae were fed on either Bt or WT OSR leaf discs $(3.8 \mathrm{~cm})$ for $24 \mathrm{~h}$. Bt leaf discs were from the plants described above. The known Bt CrylAc concentration $\left(0.092 \pm 0.011 \mathrm{ng} / \mathrm{mm}^{2}\right.$ leaf area) was multiplied by the disc area $\left(1134 \mathrm{~mm}^{2}\right)$ to obtain the total Bt CrylAc supply in leaf. In initial experiments, three samples [consisting of lots of either 10 (one sample) or 20 larvae (two samples)] of individual P. xylostella were taken and the amount of Cry $\mathrm{lAc}$ in each individual insect feeding on Bt OSR contained in each of three dishes, respectively, was quantified using ELISA and the mean value per larvae in each dish was calculated, and the total mean was assumed to be the Cry lAc of each first instar larvae used as prey for lacewing larvae in the following experiments. Subsequently, more first instar P. xylostella larvae were reared either on Bt or WT OSR. Ten of the P. xylostella larvae exposed to Bt OSR were placed in each of 12 small open plastic cups, each containing a leaf disc of Bt OSR on a base of $1 \%$ Agar gel. Fluon was applied to the inner rim of the cups. One more cup with first instar P. xylostella larvae fed on WT OSR leaf discs was used as a WT control. A single predatory second instar C. carnea larva was allowed to feed on the $P$. xylostella larvae in each individual cup for $48 \mathrm{~h}$. Further P. xylostella larvae of the same instar and the same feeding period on Bt or WT OSR, as appropriate, were added to the cups as prey was consumed by the C. carnea larvae. The average CrylAc value was multiplied by the number of $P$. xylostella larvae consumed by each C. carnea larva, and the result assumed to be the total amount of CrylAc the C. carnea larvae had ingested. Three of the lacewings fed on the $P$. xylostella larvae, which had ingested Bt OSR, were then transferred to feed on P. xylostella larvae fed on WT OSR. Two were collected after $24 \mathrm{~h}$ and the last larva after $48 \mathrm{~h}$ feeding on WT OSR, respectively. ELISA was used to quantify CrylAc content in each lacewing. Three further lacewing larvae were treated with Bt OSR at a later stage using the same methodology. A total of six Bt Cryl Ac-treated C. carnea larvae were therefore tested for CrylAc levels using ELISA, three after $24 \mathrm{~h}$ and three after $48 \mathrm{~h}$. A lacewing fed on P. xylostella larvae reared on WT OSR was used as a negative control. All lacewing larvae were collected and stored at $-80^{\circ} \mathrm{C}$ for Cryl Ac assay. 
Calculation of leaf area consumed by P. xylostella larvae

Image analysis was performed using the MATLAB software (MathWorks Inc. 1999) to facilitate the fast estimation of feeding area. Leaf discs were scanned into grey scale images, in which areas not consumed by $P$. xylostella larvae were black while the white areas representing feeding holes, and the total pixels in the image calculated. The feeding area $\left(\mathrm{mm}^{2}\right)$ was then computed by multiplying the actual leaf disc area $\left(1134 \mathrm{~mm}^{2}\right.$; diameter $\left.=3.8 \mathrm{~cm}\right)$ by the ratio of white pixels to the total pixels in the image.

\section{ELISA}

CrylAc concentrations in insect material were quantified using the commercial Btk ELISA PathoScreen kit (Agdia Inc., Elkhart, IN, USA). Frozen or fresh insects or faeces were placed in a $1.5 \mathrm{ml}$ centrifuge tube and mixed with $0.4 \mathrm{ml} 1 \times$ MEB buffer, which was obtained by mixing PBST buffer (phosphate-buffered saline plus $0.05 \%$ Tween-20) with dried milk power and Tween-20 provided in the kit. Immediately after the addition of MEB buffer, the samples were homogenized for approximately $10 \mathrm{~s}$ at a medium speed by a screw drill adapted with plastic homogenizer tips and were centrifuged at $18000 \mathrm{~g}$ for $10 \mathrm{~min}$ according to the instructions provided. Following centrifugation, $100 \mu \mathrm{l}$ volume of supernatant was dispensed into each well of a 96-well microplate provided with the kit and an ELISA test conducted. As suggested by the manufacturer the CrylAc ELISA kit had 30\% cross-reaction with CrylAb, however no reaction with other proteins was observed. Insects fed WT OSR plants or their faeces were always used as controls to avoid false-positive reactions with other components inside the insect bodies. Thus, two controls were utilized in this study: one was the above WT control and the other the negative CrylAc protein standard provided by Agdia Inc. For the quantification of CrylAc in plant leaves, fresh leaf discs ( $1.8 \mathrm{~cm}$ diameter) were homogenized and assayed as described in Wei et al. (2005). Total CrylAc protein was divided by the total leaf disc area $\left(254 \mathrm{~mm}^{2}\right)$ and CrylAc concentration per $\mathrm{mm}^{2}$ leaf area was obtained.

\section{Statistical analysis}

The CrylAc concentration of test samples was obtained from their ELISA optical density (OD) value (absorbency) via interpolation from an exponential curve fitted to the absorbency values of CrylAc standards using the statistical package GenStat (Genstat 5 Committee 1997). The REG procedure of the analysis of variance (ANOVA) module (SAS Institute 1998) was used to summarize the relationship between CrylAc in predators' bodies and amount of total consumed by lacewings, the linear regression was constrained to go through the origin to obtain good sensitivity. Regressions were also conducted to check if total amount of CylAc consumed by $P$. xylostella larvae affected total recovery of CrylAc from both larvae bodies and faeces (regression with linear and quadratic terms) and if it affected the proportion of recovered CrylAc from either larvae bodies or faeces (linear regression only).

\section{Results}

Time needed by $P$. xylostella larvae to replace their gut content

One hour after $P$. xylostella larvae had been transferred from OSR to red cabbage, faeces of all 12 larvae tested were still green. One hour later, their faeces were red. Similarly, $\mathrm{l}$ h after $P$. xylostella larvae had been transferred from red cabbage to OSR, their faeces were still red but $1 \mathrm{~h}$ later, their faeces were green. These results showed that $2 \mathrm{~h}$ is sufficient to replace the gut contents of the larvae.

\section{Cryl Ac levels in P. xylostella larvae and their faeces}

After transferring from transgenic food to WT, the larvae appeared to be either not active (experiment 1), or actively feeding (experiment 2) (table 1). In experiment 1, the percentage of CrylAc present in the bodies of $P$. xylostella larvae bodies and their faeces decreased with time larvae fed on WT OSR (fig. 1). In experiment 2, the percentage of CrylAc present in the faeces of $P$. xylostella larvae increased for $20 \mathrm{~h}$ following transfer and then decreased. The percentage of CrylAc inside the larvae (fig. 1) was consistently low probably due to active replacement of gut content by active feeding on WT OSR. In experiment 1, the maximum proportion of CrylAc found inside $P$. xylostella larvae was $12.2 \% 4 \mathrm{~h}$ after switching of food. At this stage, the proportion of CrylAc detected in faeces was $54.1 \%$ of total ingested. In experiment 2, the maximum proportion of CrylAc found in faeces was $66.5 \%$ at $20 \mathrm{~h}$ after switching of the food while only $0.26 \%$ of CrylAc 
(a)

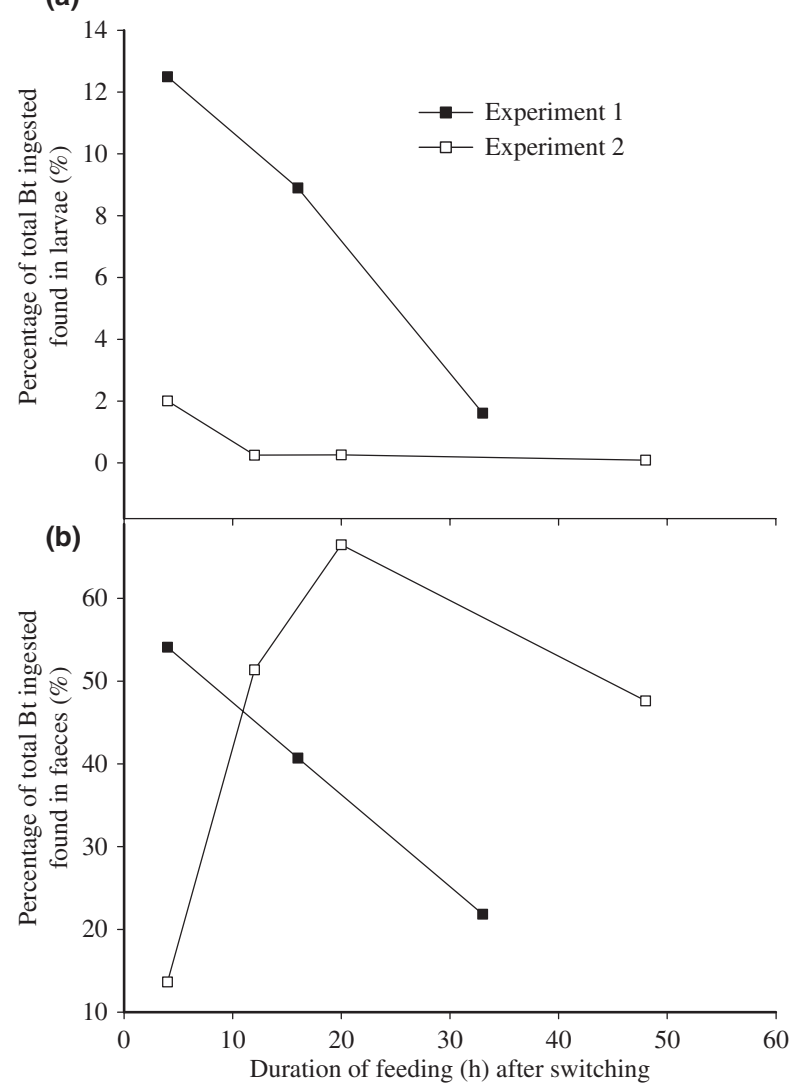

Fig. 1 Presence of Cry1Ac proteinin (a) larvae of $P$. xylostella and (b) their faeces after switching foods from transgenic Bt to wild-type oilseed rape.

was found inside larvae themselves. The total detectable percentage of CrylAc ranged from $15.7 \%$ to $66.8 \%($ mean $=45.9 \pm 7.43 \%, \mathrm{n}=7)$. There was a difference of $33.2-84.3 \% \quad($ mean $=54.1 \pm 7.43 \%$, $\mathrm{n}=7$ ) between total ingested amount and total detectable amount of CrylAc in larvae and their faeces.

\section{Cry 1 Ac levels in parasitoid larvae}

Only three parasitoids emerged in the combined dish (table 2). Four wasp larvae emerged in each of the other two dishes and six wasps emerged in the control dish. On the second occasion three, two, seven, four and one wasps, respectively, emerged from hosts in each of five dishes and eight wasps emerged from the control. Therefore, the total number of parasitoid larvae recovered was 28 from the $11 \mathrm{Bt}$-treated dishes, the latter was translated to eight dishes after dish combining, and 14 from the two control dishes, which was lower than expected as some host
Table 2 Distribution of Bt protein (ng) in larval bodies and faeces of P. xylostella during the parasitoid assay

\begin{tabular}{|c|c|c|c|c|c|}
\hline Occasion & Dish & $\begin{array}{l}\text { Amount in } \\
\text { larvae } \\
\text { bodies }\end{array}$ & $\begin{array}{l}\text { Amount in } \\
\text { faeces }\end{array}$ & $\begin{array}{l}\text { Total } \\
\text { amount }\end{array}$ & $\begin{array}{l}\text { Amount } \\
\text { elsewhere }\end{array}$ \\
\hline \multirow[t]{3}{*}{1} & 1 & 0.3254 & 6.3905 & 65.09 & 58.3741 \\
\hline & 2 & 0.7024 & 5.3895 & 95.09 & 88.9981 \\
\hline & $3{\text { (combined })^{1}}^{1}$ & 2.2001 & 12.6165 & 421.67 & 406.8534 \\
\hline \multirow[t]{5}{*}{2} & 4 & 0.2225 & 7.6041 & 173.144 & 165.3174 \\
\hline & 5 & 0.1549 & 4.7174 & 276.368 & 271.4957 \\
\hline & 6 & 1.445 & 10.9002 & 518.696 & 506.3508 \\
\hline & 7 & 0.48 & 2.4112 & 241.592 & 238.7008 \\
\hline & 8 & 2.5024 & 7.5591 & 197.156 & 187.0945 \\
\hline
\end{tabular}

${ }^{1}$ Hosts in four dishes were combined together due to death of the P. xylostella larvae.

larvae died probably due to superparasitism during the exposure of $24 \mathrm{~h}$. CrylAc concentration in parasitoids recovered from Bt toxin-treated dishes was found to be zero estimated by interpolation from an exponential curve fitted to the absorbency values of CrylAc standards. In addition, the absolute absorbency read by microplate scanner for each parasitoid larva was compared with the absorbency of $\mathrm{Bt}$ CrylAc protein negative standard and that of parasitoids from the WT control. All the values were lower than either those of the CrylAc negative standard and the WT control (data not shown here). This confirmed that CrylAc could not be detected inside the parasitoid larvae.

After a maximum 3 days' feeding the larvae stopped eating. The totally accumulated consumption of Bt CrylAc protein varied among replicates and ranged from 65 to 519 ng (table 2 ). On average only $4.4 \%(\mathrm{SE}=1.05, \mathrm{n}=8)$ of the CrylAc consumed was found in either P. xylostella larvae or their faeces, as estimated from the CrylAc recovery data. The regression equation for the relationship between total CrylAc consumed $(x)$ and total recovered $(y)$ in both linear and quadratic terms was $y=0.1281-$ $0.000618 x+0.000000838 x^{2}\left(R^{2}=0.814\right)$. Therefore, there was evidence of a decrease in the proportion of CrylAc recovered with increasing amount consumed $\left(F_{1,5}=12.35, \mathrm{P}=0.017\right)$, with some additional curvature $\left(F_{1,5}=9.54, \mathrm{P}=0.027\right)$ that suggests that the recovered CrylAc toxin may increase again with higher amounts consumed (fig. 2). On average $11.3 \pm 2.69 \%$ of recovered Cryl Ac was found in larval bodies and $88.7 \pm 2.69 \%$ of recovered Cryl Ac in their faeces. The linear regression equation for the relationship between the proportion of recovered toxin in larval bodies $(y)$ and the total amount eaten 


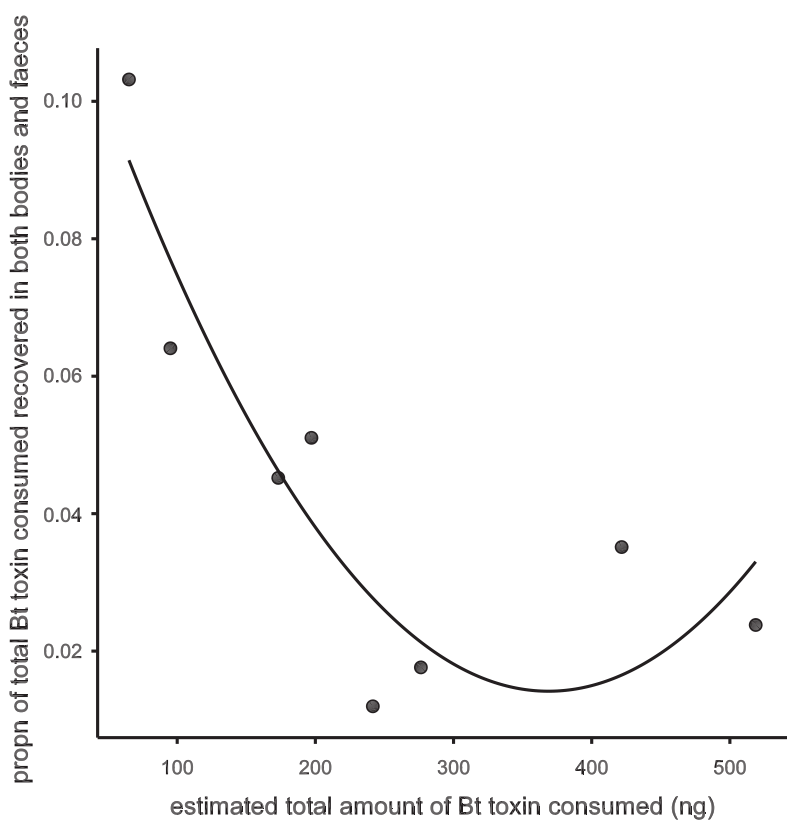

Fig. 2 Regressions of recovery of Bt toxin from larvae bodies and faeces on total amount consumed by caterpillar larvae. $190 \times 190 \mathrm{~mm}$ $(600 \times 600 \mathrm{DPI})$

(x) was $y=0.0903+0.000092 x$, in which slope of the regression line was not different from zero and no significant evidence detected $\left(R^{2}=0.035\right.$, $\left.F_{1,6}=0.22, \quad \mathrm{P}=0.657\right)$. This relationship could be also described by the constant model $y=0.1130$, for which the $R$-squared was nearly zero while the standard error of the intercept is 0.0269 and there is evidence that the intercept is bigger than zero $\left(t_{7}=4.21, \mathrm{P}<0.01\right)$. Neither proportion of CrylAc recovered in larvae or that in their faeces was affected by total amount Cryl Ac eaten.

\section{CrylAc levels inside predatory lacewings}

The average amount of CrylAc present in each first instar $P$. xylostella larvae feeding on Bt OSR leaf discs was $0.155,0.019$ and $0.122 \mathrm{ng}$ in each of the three dishes, respectively, and the total mean was $0.098 \pm 0.041 \mathrm{ng}$ (fig. 3). The total levels of Cryl Ac estimated to be present in each $C$. carnea larva after feeding are shown in fig. 4. The total estimated amount of CrylAc ingested by $C$. carnea larvae ranged from 0.787 to $5.02 \mathrm{ng}$ per larva $(2.44 \pm$ $0.467 \mathrm{ng}, \mathrm{n}=9$ ). However, CrylAc could not be detected in two of the lacewings even though they were known to have eaten some $P$. xylostella larvae feeding on Bt OSR. CrylAc residual in lacewing larvae ranged from zero to $0.33 \mathrm{ng}$ per larva (mean $0.15 \pm 0.041 \mathrm{ng}, \mathrm{n}=9$ ) (fig. 3), that were still actively preying at the end of the assay. A significant linear relationship $\left(F_{1,8}=38.03, \mathrm{P}<0.001\right)$ was found between the detectable amount of CrylAc in C. carnea larvae and the estimated amount of Cryl Ac they had ingested (fig. 4). The average proportion of observed/ingested CrylAc for C. carnea larvae was $6.22 \pm 1.773 \%(\mathrm{n}=9)$, ranging from 0 to $13.9 \%$.

The total amount of CrylAc ingested by the first three $C$. carnea larvae tested was estimated as 0.98 , 1.38 and $1.57 \mathrm{ng}$ per larva, respectively (based on the number of $P$. xylostella larvae consumed). However, no CrylAc toxin was detected in these three lacewings following their transfer from Bt-fed prey to WT-fed prey for either 24 or $48 \mathrm{~h}$. Their absorbency values were lower than that of the wild control as read by a microplate scanner (data not shown). We tested three more $C$. carnea larvae (but without monitoring the number of prey larvae they consumed). The absorbency of the one $C$. carnea larva collected after $48 \mathrm{~h}$ feeding on $P$. xylostella
Fig. 3 The Bt Cry1 Ac toxin movement through trophic levels of a simple food chain: plant-insect pest (prey)-predator in agro-ecosystem. The error bar stands for SE.

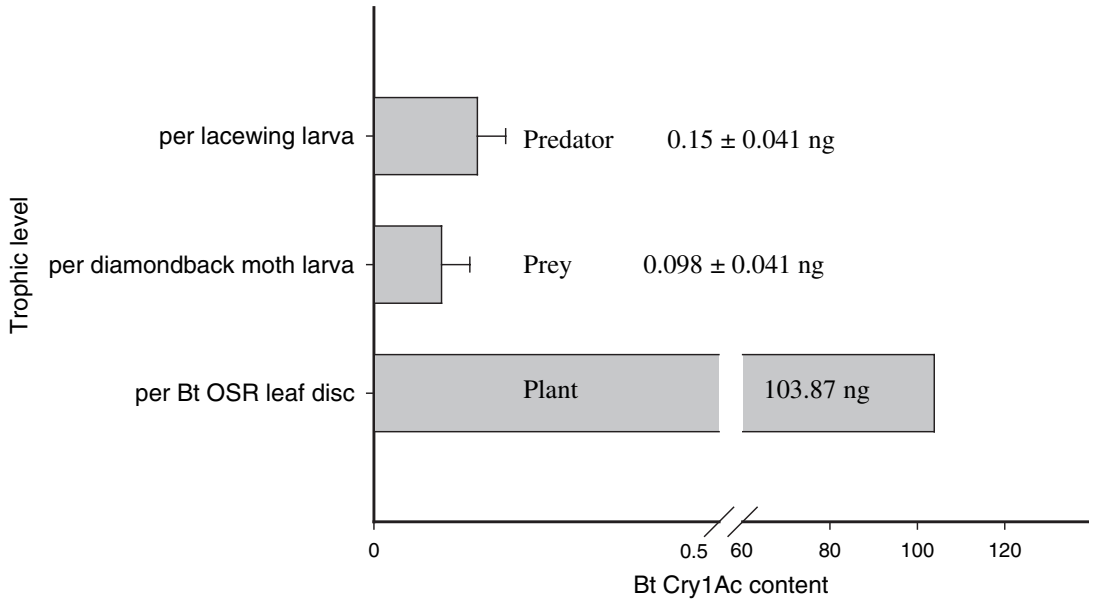




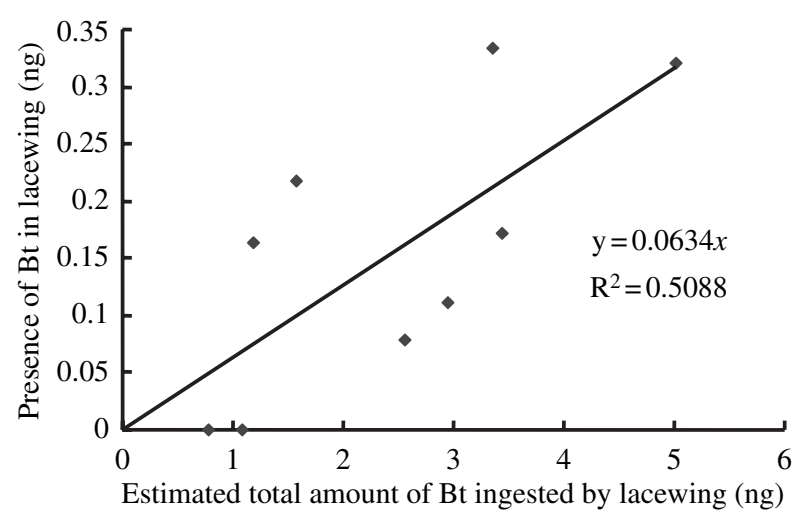

Fig. 4 Presence of $\mathrm{Bt}$ toxin in C. carnea larvae in relation to the estimated amount of Bt toxin they ingested $(n=9)$.

larvae exposed to WT OSR was lower than that of the Bt toxin-negative standard provided by Agdia Inc. The absorbency values of another two C. carnea larvae tested were slightly higher than those of both the WT control and the Bt toxin-negative standard, translating to $0.02 \mathrm{ng}$ of Cryl Ac per C. carnea larva.

\section{Discussion}

Our development of the red cabbage/OSR diet series assay to induce a faeces colour change, and hence determine the time required to change gut contents was successful and has not been reported previously in the literature. The results were important in developing assays examining movement of Bt protein through trophic levels. This is a novel assay that could have other uses in insect physiology and ecology. However, this assay was only a simple way to obtain an approximate estimate of the appropriate period. In addition, faeces colour changes did not necessarily mean that a complete gut content exchange had taken place. Small proportions of red cabbage in the faeces might not be detected by eye but is probably masked by greencoloured contents. More accurate data might be obtained through radioisotopic-labelling methods (Wright et al. 1985).

Twice the required time of replacing gut content was allowed in these assays thus the measured Bt protein concentration here in the larvae should be the actual fraction integrated inside the larval body. Though much different results were found between the two feeding experiments of less replicates with different conditions, in which either active or inactive feeding behaviours presented while Bt toxin in larvae was not assayed immediately after the switching of food, the decrease of CrylAc in larval bodies was suggested that justified enclosing transgenic leaf discs during the following exposure bioassays. In addition, our results showed that more Bt toxin was present in the faeces than in the bodies of P. xylostella. This suggested that more Bt protein came through the larval gut than stayed in the body. However, while using a CrylAc-tolerant insect Spodoptera exigua in a feeding bioassay, no difference was detected in the amount of CrylAc between larval bodies and faeces (Shi et al. 2006). Nevertheless, our finding was consistent with the report of lacking of binding site of Bt CrylAc in the gut of the resistant strain (NO-QA) of $P$. xylostella (Tabashnik et al. 1997) but imply plentiful Bt CrylAc toxin presenting somewhere else inside the larval bodies.

The saturated CrylAc homogenous solution would enable full quantification of the concentration of samples with calibrated standards using ELISA test. The sum of CrylAc in the bodies of P. xylostella larvae and their faeces was much less than the estimated total toxin taken up by the $P$. xylostella larvae. This suggests that the balance of Bt proteins between consumed and detected was probably metabolized by Bt-resistant P. xylostella larvae. However, the increase of recovery Cryl Ac found in fig. 2 implied that there was a limitation in metabolic ability when the total consumed CrylAc protein reached a certain amount. In the experiments with $C$. vestalis, in which P. xylostella larvae were kept on Bt OSR during the whole duration of the experiment, the sum of total recovered $\mathrm{Bt}$ toxin in both $P$. xylostella larvae and their faeces was less than that recovered in the food switching experiment. This result might be due to degradation of $\mathrm{Bt}$ protein during the longer duration of the bioassays. After parasitization, it took about 3 days for the hosts to stop feeding, during that period the faeces of the hosts were not collected and exposed to room temperature for 3 days before being collected and stored in $-80^{\circ} \mathrm{C}$.

To our knowledge, the present study is the first study to test for the presence of Bt toxin in parasitoid larvae shortly after their emergence from Bt-plant-fed hosts. No Bt protein was detected in the newly emerged parasitoid $C$. vestalis larvae which provides further evidence for the hypothesis of Schuler et al. (2004) that this parasitoid may not be exposed to CrylAc when feeding on Bt-plant-fed hosts during its larval development. A study with a related endoparasitoid species, Cotesia marginiventris (Gresson) (Hymenoptera: Braconidae), also found no detectable levels of the $\mathrm{Bt}$ toxin Cryl $\mathrm{Ab}$ in adult 
C. marginiventris when the parasitoids developed on Bt maize-fed larvae of Spodoptera littoralis (Boisduval) (Lepidoptera: Noctuidae) (Vojtech et al. 2005). Sanders (2005) found a low level of Cryl Ab in the pupae of the hymenopteran endoparasitoid Campoletis sonorensis (Cameron) (Hymenoptera: Ichneumonidae), a parasitoid species that in contrast to $C$. vestalis consumes most of the host tissues before pupation, reared in Bt maize-fed hosts, but no evidence for the presence of Cryl Ab within adult C. sonorensis.

When P. xylostella larvae exposed to Bt OSR were fed to predatory $C$. carnea larvae, a natural enemy that consumes most of the tissues of its prey, CrylAc was found to be present in the $C$. carnea larvae. Residual Bt toxin in C. carnea larvae was significantly related to the amount of $\mathrm{Bt}$ toxin they ingested, despite the relatively large variation between individuals. In lacewings defecation takes place only after imaginal moulting and the meconium accumulates in the midgut during larvae development (McEwen et al. 2001). Lacewing larvae in the present study therefore did not have the opportunity to excrete the CrylAc toxin during the duration of the experiments. The fact that (1) no CrylAc was detected in two $C$. carnea larvae after they had consumed several prey insects reared on Bt OSR and (2) in seven C. carnea larvae less than $35 \%$ of the ingested CrylAc was detected strongly indicates that C. carnea is able to metabolize plant-produced CrylAc. Although there were less replicates due to time limitation, this result is in line with findings of Romeis et al. (2004) with microbially produced trypsinized CrylAb, in which they fed CrylAb to C. carnea larvae in sucrose solution. These authors detected no Cryl Ab toxin in C. carnea larvae 6 days after Cryl Ab ingestion. Their results also suggest that the detectable amount of CrylAb toxin within the C. carnea larvae was reduced by half within $24 \mathrm{~h}$ after ingestion of Cryl Ab. In our study, it was demonstrated that the amount of CrylAc was low or could not be detected 24-48 h after the lacewings were transferred from CrylAc-fed prey to prey reared on non-transgenic plants. However, caution should be taken regarding the limitation in detection level of ELISA when drawing any valid conclusion. If the amount of CrylAc inside larvae were below the limits of detection, even the relative low absorbency than negative control might not guarantee the absence of CrylAc. In addition, the metabolized toxin could become undetectable but probably with potential activity.

Though both herbivorous insect preys and the predators could metabolize Bt toxin, that does not necessarily mean the absence of the bioactivity of the metabolized toxin (Shi et al. 2006). The present study suggests that the parasitoid C. plutella was not exposed to $\mathrm{Bt}$ protein while the predator $C$. carnea was exposed to a relatively large amount. However, in the field $C$. carnea feeds on a wide range of softbodied insects (McEwen et al. 2001) and, unlike in the field, $C$. carnea larvae did not have a choice of prey in the present study as the aim was to conduct a 'worst case scenario' test (Lovei and Arpaia 2005). Aphids are particularly important prey for C. carnea (Meier and Hilbeck 2001). Predators are, however, unlikely to be exposed to Bt toxins via aphid prey as studies suggest that aphids do not ingest CrylA toxins when feeding on Bt oilseed rape (Schuler et al. 2005) or Bt maize (Head et al. 2001; Raps et al. 2001). Lacewings under field conditions experience variable temperatures, prey choice, several different prey types, food shortage and predation risks (Lovei and Arpaia 2005) and, nevertheless, also other additional routes, e.g. pollen feeding that would increase the exposure to Bt toxin, thus the amount of Bt toxin of lacewing larvae being exposed to in the field would be less or more than the result reported in the present worst case scenario study.

\section{Acknowledgements}

This work was funded by a Rothamsted International Fellowship. WW also received a grant from the Natural Science Foundation of China (NSFC) (grant no. 30670316). Grants to CNS from the USDA Biotechnology Risk Assessment panel facilitated this research. We would like to thank Dr Xiangcheng Mi and Mr Zhixi Tang, Institute of Botany, Chinese Academy of Sciences (CAS), China, for help with statistical analysis, A. Clark and C. Denholm, Rothamsted Research, UK, for technical assistance, and Dr Chet Sutula from Agdia Incorporated, USA, for useful advice on use of the Bt kit. We appreciate two anonymous reviewers whose comments help to improve this paper and Prof. Hong Jiang, Nanjing University, China, for a discussion on an early version of the manuscript.

\section{References}

Dutton A, Klein H, Romeis J, Bigler F, 2002. Uptake of Bt-toxin by herbivores feeding on transgenic maize and consequences for Chrysoperla carnea. Ecol. Entomol. $27,441-447$.

Dutton A, Romeis J, Bigler F, 2003. Assessing the risks of insect resistant transgenic plants on entomophagous 
arthropods: Bt-maize expressing Cryl Ab as a case study. BioControl 48, 611-636.

Genstat 5 Committee, 1997. Genstat 5 Release 4.1 Command Language Manual. Numerical Algorithms Group, Oxford.

Harwood JD, Wallin WG, Obrycki JJ., 2005. Uptake of Bt endotoxins by nontarget herbivores and higher order arthropod predators: molecular evidence from a transgenic corn agroecosystem. Mol. Ecol. 14, 2815-2823.

Head G, Brown CR, Groth ME, Duan JJ, 2001. Cryl Ab protein levels in phytophagous insects feeding on transgenic corn: implication for secondary exposure risk assessment. Entomol. Exp. Appl. 99, 37-45.

Hilbeck A, Schmidt JEU, 2006. Another view on Bt proteins - how specific are they and what else might they do? Biopestic. Int. 2, 1-50.

Hilbeck A, Baumgartner M, Fried PM, Bigler F, 1998a. Effects of transgenic Bacillus thuringiensis corn-fed prey on mortality and development time of immature Chrysoperla carnea (Neuroptera: Chrysopidae). Environ. Entomol. 27, 480-487.

Hilbeck A, Moar WJ, Pusztai-Carey M, Filippini A, Bigler F, 1998b. Toxicity of Bacillus thuringiensis Cryl Ab toxin to the predator Chrysoperla carnea (Neuroptera: Chrysopidae). Environ. Entomol. 27, 1255-1263.

Hilbeck A, Moar WJ, Pusztai-Carey M, Filippini A, Bigler F, 1999. Prey-mediated effects of Cryl Ab toxin and protoxin and Cry2A protoxin on the predator Chrysoperla carnea. Entomol. Exp. Appl. 91, 305-316.

Le YT, Stewart CN Jr, Shi H, Wei W, Mi X-C, Ma K-P, 2007. Expression of Bt crylAc in transgenic oilseed rape in China and transgenic performance of intraspecific hybrids against Helicoverpa armigera larvae. Ann. Appl. Biol. 150, 141-147.

Lovei GL, Arpaia S, 2005. The impact of transgenic plants on natural enemies: a critical review of laboratory studies. Entomol. Exp. Appl. 114, 1-14.

MathWorks, 1999. Matlab, V. 6.5. The MathWorks Inc., Natick, MA.

McEwen PK, New TR, Whittington AE, 2001. Lacewings in the crop environment. Cambridge University Press, Cambridge.

Meier MS, Hilbeck A, 2001. Influence of transgenic Bacillus thuringiensis corn-fed prey and prey preference of immature Chrysoperla carnea (Neuroptera: Chrysopidae). Basic Appl. Ecol. 2, 35-44.

Nguyen HT, Jehle JA, 2007. Quantitative analysis of the seasonal and tissue-specific expression of Cryl Ab in transgenic maize Mon810. J. Plant Dis. Prot. 114, 820-887.

Orr DB, Landis DA, 1997. Oviposition of European corn borer (Lepidoptera: Pyralidae) and impact of natural enemy population in transgenic versus isogenic corn.

J. Econ. Entomol. 90, 905-909.

Pilcher CD, Obrycki JJ, Rice ME, Lewis LC, 1997.

Preimaginal development, survival, and field abundance of insect predators on transgenic Bacillus thuringiensis corn. Environ. Entomol. 26, 446454.

Raps A, Kehr J, Gugerli P, Moar WJ, Bigler F, Hilbeck A, 2001. Immunological analysis of phloem sap of Bacillus thuringiensis corn and of the nontarget herbivore Rhopalosiphum padi (Homoptera: Aphididae) for the presence of Cryl Ab. Mol. Ecol. 10, 525-533.

Romeis J, Dutton A, Bigler F, 2004. Bacillus thuringiensis toxin (Cryl Ab) has no direct effect on larvae of the green lacewing Chrysoperla carnea (Stephens) (Neuroptera: Chrysopidae). J. Insect Physiol. 50, 175-183.

Romeis J, Meissle M, Bigler F, 2006. Transgenic crops expressing Bacillus thuringiensis toxins and biological control. Nat. Biotech. 24, 63-71.

Sanders C, 2005. Interactions between Spodoptera frugiperda and two of its natural enemies on conventional and Bt maize. PhD Thesis, University of Southampton.

SAS Institute, 1998. SAS/STAT user's guide: Statistics. SAS Institute, Cary, NC.

Schuler TH, Potting RPJ, Denholm I, Poppy GM, 1999. Parasitoid behaviour and Bt plants. Nature 400, 825-826.

Schuler TH, Denholm I, Jouanin L, Clark SJ, Clark AJ, Poppy GM, 2001. Population-scale laboratory studies of the effect of transgenic plants on nontarget insects. Mol. Ecol. 10, 1845-1853.

Schuler TH, Denholm I, Clark SJ, Stewart CN Jr, Poppy GM, 2004. Effects of Bt plants on the development and survival of the parasitoid Cotesia plutellae (Hymenoptera: Braconidae) in susceptible and Bt-resistant larvae of the diamondback moth, Plutella xylostella (Lepidoptera: Plutellidae). J. Insect Physiol. 50, 435-443.

Schuler TH, Clark AJ, Clark SJ, Poppy GM, Stewart CN Jr, Denholm I, 2005. Laboratory studies of the effect of reduced prey choice caused by Bt plants on a predatory insect. Bull. Entomol. Res. 95, 243-247.

Shi H, Zhang L-F, Hua B-Z, Mi X-C, Wei W, Zhang Y-J, Ma K-P, 2006. Insecticidal activity of residual Bt protein at the second trophic level. Chin. Bull. Sci. 51, 946-951.

Stewart CN Jr, Adang MJ, All JN, Raymer PL, Ramachandran S, Parrott WA, 1996. Insect control and dosage effects in transgenic canola containing a synthetic Bacillus thuringiensis crylAc gene. Plant Physiol. 112, 115-120.

Stewart CN Jr, Halfhill MD, Warwick SI, 2003. Transgene introgression from genetically modified crops to their wild relatives. Nat. Rev. Genet. 4, 806-817.

Tabashnik BE, Liu Y-B, Malvar T, Heckel DG, Masson L, Ballester V, Grtanero F, Mensua JL, Ferre J, 1997. Global variation in the genetic and biochemical basis of diamondback moth resistance to Bacillus thuringiensis. Proc. Natl. Acad. Sci. USA 94, 12780-12785. 
Talekar NS, Shelton AM, 1993. Biology, ecology, and management of the diamond back moth. Ann. Rev. Entomol. 38, 275-301.

Vojtech E, Meissle M, Poppy GM, 2005. Effects of Bt maize on the herbivore Spodoptera littoralis (Lepidoptera: Noctuidae) and the parasitoid Cotesta marginiventris (Hymenoptera: Braconidae). Transgen. Res. 14, 133144.

Wei W, Qian Y-Q, Ma K-P, 1999. Gene flow between transgenic crops and their wild related species. J. Integr. Plant Biol. (Acta Bot. Sin.) 41, 343-348.
Wei W, Schuler TH, Clark SJ, Stewart CN Jr, Poppy GM, 2005. Age-related increase in levels of insecticidal protein in the progenies of transgenic oilseed rape and its efficacy against a susceptible strain of diamondback moth. Ann. Appl. Biol. 147, 227-234.

Wright JP, Fisher DB, Mittler TE, 1985. Measurement of feeding rates on artificial diets using ${ }^{3} \mathrm{H}$-inulin. Entomol. Exp. Appl. 37, 9-11.

Zwahlen C, Andow DA, 2005. Field evidence for the exposure of ground beetles to Cryl $\mathrm{Ab}$ from transgenic corn. Environ. Biosafety Res. 4, 113-117. 